\title{
Lusisersily
}

\section{'A Pleasingly Blank Canvas': Urban Regeneration in Northern Ireland and the Case of Titanic Quarter}

Ramsey, P. (Accepted/In press). 'A Pleasingly Blank Canvas': Urban Regeneration in Northern Ireland and the Case of Titanic Quarter. Space and Polity, 17(2), 164 -179. https://doi.org/10.1080/13562576.2013.817513

Link to publication record in Ulster University Research Portal

Published in:

Space and Polity

Publication Status:

Accepted/In press: 01/02/2013

DOI:

10.1080/13562576.2013.817513

\section{Document Version}

Author Accepted version

\section{General rights}

Copyright for the publications made accessible via Ulster University's Research Portal is retained by the author(s) and / or other copyright owners and it is a condition of accessing these publications that users recognise and abide by the legal requirements associated with these rights.

\section{Take down policy}

The Research Portal is Ulster University's institutional repository that provides access to Ulster's research outputs. Every effort has been made to ensure that content in the Research Portal does not infringe any person's rights, or applicable UK laws. If you discover content in the Research Portal that you believe breaches copyright or violates any law, please contact pure-support@ulster.ac.uk. 
'A Pleasingly Blank Canvas': Urban Regeneration in Northern Ireland and the Case of Titanic Quarter

\author{
Phil Ramsey, Ulster University \\ pt.ramsey@ulster.ac.uk
}

http://ulster.academia.edu/PhilRamsey | http://orcid.org/0000-0001-5873-489X

\title{
Published as:
}

Ramsey, P. (2013). 'A Pleasingly Blank Canvas': Urban Regeneration in Northern Ireland and the Case of Titanic Quarter. Space and Polity. 17(2), 164-179.

(http://dx.doi.org/10.1080/13562576.2013.817513)

\begin{abstract}
The ongoing development of Titanic Quarter in Belfast, Northern Ireland, has already made significant changes to the area. The site on which the Titanic was built has been redeveloped as an area for tourism, business, education and the creative industries. The site has been developed following a significant inflow of private capital, and with the additional support of local government and public finance. This article outlines how economic and political forces have coalesced in Belfast to the point that the violent period of the 'Troubles' in Northern Ireland can be said to have created a 'pleasingly blank canvas for regeneration'.
\end{abstract}


Belfast is unique among Western European cities in that more than half of its city centre has yet to be redeveloped, creating a pleasingly blank canvas for regeneration. (Harcourt Developments, 2007)

\section{Introduction}

The ethno-political conflict in Northern Ireland - colloquially known as the 'Troubles' - lasted roughly from 1968 to 1998 , in its most recent and violent phase. Charting a beginning and end to the Troubles is difficult, as the conflict was rooted in centuries of strife and political turmoil, and some violence remains to the present day. This period in Northern Ireland (NI) was marked by economic stagnation in the province, marked by high levels of unemployment (compared to Great Britain). Reports in 2010 showed that, in the twelve years since the Good Friday Agreement was signed, unemployment stood at the same level, and economic inactivity for the NI population aged 16-64 at 28.6\% (as compared to the UK average of 23.2) (Magee, 2010). The UK Treasury's 'subvention' to NI was realised in higher levels of public sector spending compared to England, Scotland and Wales, as the NI economy struggled "to keep pace with the restructuring of the British economy in the 1970s and 1980s..." (Darby, 2003). When the Good Friday Agreement (GFA) was signed in 1998 (NIO, 1998) (bringing relative political stability), many politicians and business people hoped that large amounts of capital would flow into NI, thus stimulating the private sector. This article discusses how the effects of political and economic change in NI were played out in the 
development of the built-environment, as seen in the development of Titanic Quarter (TQ).

Titanic Quarter, situated on banks of the River Lagan in the capital city Belfast, is a mixed residential, commercial and leisure space, at the site where the Titanic was constructed. It is similar to many other riverside development projects around the world, and has seen the inflow of both large amounts of private capital and public finance, outlined later in this article. This has gone towards filling space left over from the period of heavy industry and manufacturing (largely focused on ship building) that defined the nineteenth and twentieth centuries in major UK ports. This article engages with the arguments put forward by the developers of TQ that Titanic Quarter is intended for the wider benefit of Northern Irish society and its economy, and posits that the emergence of TQ must be seen in the wider context of the implementation of marketisation and economic liberalisation, trends that have underpinned the development of what is often described as the 'new Northern Ireland'. It argues that such claims are unfounded, and that the development of projects like TQ primarily serves the interests of capitalist development, rather than having an extensive social and economic benefit for the wider Northern Ireland population. Methodologically, this article is a desk-based study of numerous sources, including academic research, reports from government and research organisations, company documentation from the lead developer of the Titanic Quarter site, and journalistic articles from the BBC and other sources. As these secondary sources come from a diverse range of actors and organisations, the reliance on these sources is not undue. 


\section{Establishing 'conventional economics' in Northern Ireland}

The key ideological message driven by both the Irish and British states is that peace dividends are to be achieved through conventional economics. A dropping unemployment rate, additional and religiously mixed middle-income employment and a vibrant city-centre nightlife are meant to show that Belfast is 'booming' in a different way. (Shirlow, 2006, p.101)

In his discussion of Belfast as a 'post-conflict' city, Shirlow (2006) outlines the approach that is increasingly being taken to understanding NI. Following the cessation of the worst violence from the Troubles, Belfast is now seen as a site ripe for the implementation of 'conventional economics', seen in the expansion of the market economy, the push for foreign direct investment, the withdrawal of the state from the market to bring it more into line with Great Britain and other west European states, and speculation in the land and property market. This approach can be effectively summarised by a statement from Colin Lewis of Invest NI, (a public body that supports the private sector): "Once Belfast had a terrible reputation and now it's regarded as normal" (as cited in Neill, 2006, p.112). For Invest NI, normalisation involves the goal of increasing "business productivity and boost[ing] Northern Ireland's Gross Value Added (GVA) per employee, which is around 20 per cent lower that the UK average" (Invest Northern Ireland, 2012, p.1). Such a policy position flows from the positions of successive British governments, and the settled position of New Labour post-1998 (after the signing of the GFA, when it was held that NI must begin to stand on its feet economically), and reinforced in the St. Andrews 
Agreement (NIO, 2007). Bairner (2006) notes that while such documents ratify relative levels of peace and stability, property developers and others had already decided to target NI as a site of much untapped potential: "Capital investors did not need to wait for a formal document to realise that the cessation of widespread random acts of violence together with the IRA's focus on economic and prestige targets in England had turned Belfast into place where rich profits could be made" (Bairner, 2006, p.125). Indeed, Belfast became seen by investors as a site ripe for investment, encapsulated in the publication of reports such as Economics in Peacemaking: Lessons from Northern Ireland (Portland Trust, 2007).

In the private housing market in NI, prices that had been kept low for decades due to the Troubles (as compared to similar housing in the Republic of Ireland (ROI) and Great Britain) rose sharply in value. The Nationwide bank reported in 2007 that "House prices in Northern Ireland fell in the wake of the violence and the manufacturing decline of the 1970s but began to rise again in the early 1990s when the peace process gathered momentum and the growth of manufacturing in Northern Ireland started to outpace growth of this sector in the rest of the UK" (as cited in Portland Trust, 2007, p.3). In the built-environment, the biggest changes that occurred were in the private homes market. Belfast became populated with cheaply and quickly constructed apartment complexes, designed in a way as to make them indistinguishable from other UK or European cities. While the housing market had previously been marked by an absence of private apartments (such dwellings rather being used as social housing), these soon became a feature along Belfast's Lagan River, not far from the site of TQ. From 2007 onwards, NI 
house prices went into decline, with the Royal Institution of Chartered Surveyors finding that average house prices fell 48 per cent between the peak of the market and 2012 (as cited in Canning, 2012). Given that a lot of investment in NI was from the ROI, when the Irish housing market collapsed many Irish investors could no longer service their debts. As a result, many NI assets transferred into the ownership of the ROI government's 'bad bank', NAMA (National Asset Management Agency, established in December 2009). As of 2012, NAMA held $£ 3.35$ bn worth of property in NI (4 per cent of NAMA's total assets) (Fitzpatrick, 2012). In June 2012, as though to highlight the severity of the house price problem in NI, the chairman of the global-national bank RBS Sir Philip Hampton singled out its Irish division as the company's biggest cause for concern. Hampton stated that the Ulster Bank had "overdosed" on property development, and that the RBS "simply didn't expect the scale of problems in Ireland" (BBC, 2012a). While this is reflective of the Ulster Bank's activities throughout the whole all of Ireland (in both NI and the ROI), it is worth noting that the population of NI is relatively small, standing in 2012 at an estimated 1.81 million people (NISRA, 2012). Restated, NI contributed in proportionately high terms to the failure at RBS, encapsulated by its 82 percent nationalisation in 2008 by the UK government (BBC, 2012b), and its posting of the biggest annual loss in UK corporate history. NI is sometimes lauded as "punching above its weight' in terms of culture (sport, music, film) on the UK stage, but in this case it punched above its weight in terms of financial collapse in the UK property market. Today, while Northern Ireland's economy remains in better condition compared to that of the ROI, the UK Treasury public spending cuts put it in a precarious position (Kaufmann, 2012). This situation means that NI's politicians have difficult economic choices to make, 
such as those regarding the cut in corporation tax that some propose, to bring NI in line with the taxation rate in the ROI. Another issue is the extent to which NI politicians continue to use the state to fund private sector development here, given that cases like TQ show that property developers are often the primary benefactors, at the expense of economic development that has a wider social impact.

\section{The 'New Northern Ireland'}

The drive for the establishment of 'conventional economics' in NI is often accompanied by a discourse that has emerged, seen clearly in the descriptor the 'New Northern Ireland'. Here, the 'New Northern Ireland' tends to denote that the country has shifted from violence and conflict to a post-conflict, consumer society, where sectarianism and social ills are swept aside by gentrification. The discourse of the 'New Northern Ireland', defines itself in difference to the 'Old Northern Ireland' (though this phrase is rarely used), which by implication can be taken to refer to a backward and underdeveloped country, blighted by political violence and the 'ills' of underdeveloped market economy. This can be seen in particular in voluntary and third sector documentation. In a recent Community Relations Council report, Nolan (2012) argues that "A new, confident, and neutral urban culture has emerged", where in Belfast and Londonderry "Attention has focused more on the relaxed environment of the city centres, which now boast a new "cappuccino culture"” (p.10). In response to Nolan we can think here of Sharon Zukin's phrase, "pacification by cappuccino" (as cited in Harvey, 2008, 
p.31), where progress in NI is measured according to the availability of frothy coffee. Further evidence is provided by Nolan in the form of the presence of the MTV Europe Music Awards in Belfast in 2011, and Londonderry's status as 2012 UK City of Culture. For corroboration, Nolan points to the Northern Ireland Life and Times Survey (NILT) and work by the Institute for Conflict Research (ICR), which indicates that there are more perceived 'neutral' areas than in the past, including shopping areas (Hamilton at al., 2008). However, these areas often exist alongside segregated areas, where residential segregation is the primary form of segregation, alongside education and access to sporting facilities (Byrne et al., 2006; Hamilton et al., 2008). Nolan (2012) does accept that "geographical and class boundaries persist" (p.10), the thrust of his argument is that a 'New Northern Ireland' has emerged, and that this is a positive thing: "For those with the means to participate, though, the new consumer culture is nonetheless real and marks a stage in the journey away from street violence, and towards a new sense of identity for Northern Ireland" (Nolan, 2012, p.10).

Harvey (2008), writing on urban development, argues that "Even the incoherent, bland and monotonous suburban tract development that continues to dominate in many areas now gets its antidote in a 'new urbanism' movement that touts the sale of community and boutique lifestyles to fulfill urban dreams" (p. 32). "Fulfilling urban dreams' through 'boutique lifestyles' has a relatively short history in NI, due to the impact of the Troubles, and the accompanying lack of development of the retail and leisure sectors. Shirlow (2006) and Bairner (2006) outline the role of consumption and the construction of consumer spaces in NI. Shirlow (2006) notes that in Belfast, "The 
construction of the Castle Court shopping mall, out of glass in a zone of conflict, in the 1980s was a key symbol of state control and increasing confidence. Future state expenditure on the riverfront and the use of funds to create a modern cityscape also indicated the desire to present a normal place" (pp.100-101). Moreover, Bairner (2006) draws on the development of Victoria Square - the successor to Castle Court, ostensibly marketed at a 'boutique' lifestyle — and criticises the extent to which the development of a 'City centre public realm' is a positive step. He argues: "First, there is the implication that more shops mean happier citizens and indeed that building projects are directly linked to the emergence of a society free from political violence- hence, 'the better and brighter future' that is promised" (Bairner, 2006, p.129). This was seen clearly in an advertising banner that was draped around cranes at the construction site of Victoria Square that read: 'A renaissance for Belfast' (McAllister, 2009, p.19). While both sites respectively were seen at the time of construction as being emblematic of change Castle Court in the early stages of peace and progress, Victoria Square in the property boom years - both were ultimately sites of capital accumulation that saw substantial decline for their owners. In 2012, Castle Court was sold by the multi-national Westfield, reportedly now worth half of the $£ 350$ million it was worth before the crash (BBC, 2012c). In 2011, Victoria Square had lost $£ 29$ million from its original valuation $£ 349$ million in 2008, with the German company CGI Hausinvest making the loss (BBC, 2011). 


\section{Remaining segregation in Belfast}

Shirlow and Murtagh's (2006) description of Belfast goes some way to grasping the complexity of the city: "It is one of those places within which history, identity and culture are played out, in a dramatic and public manner, through the instruments of threat, menace, violence and deviance" (p.2). Despite the major improvements in levels of peace compared to the worst years of the Troubles, and major changes in the provision of leisure and shopping facilities, Belfast remains a deeply divided and segregated city (Shirlow and Murtagh, 2006), with the population largely divided along sectarian lines in terms of housing, and with $93.5 \%$ of children educated in separate Catholic and Protestant schools (Nolan, 2012). No better is this encapsulated than by the fact that when the Good Friday Agreement was signed in 1998 there were 22 peace walls, but by 2010 there were 48 (Nolan, 2012, p.71). By another measurement - that based on work carried out by the Belfast Interface Project (2012) - there are 99 "different security barriers and forms of defensive architecture across the city associated with residential areas" (p.11). This contributes to a situation where the "vast majority of segregated residential districts are working class, spaces which hosted nearly all sectarian violence" (Nagle, 2009a, p.328). The city centre of Belfast remains contested, where Nationalists have sought equal access to what was once Unionist "sacred space" (Nagle, 2009b), seen clearly in the riots that emanated after Belfast City Council voted in 2012 to only fly the Union Jack (flag of the UK) over the city hall on certain dates, rather than every day of the year. Into this context, Shirlow and Murtagh's point, that "divided cities are places of passion, commitment and unwavering belief" (Shirlow and Murtagh, 2006, p.2), seems as 
prevalent as ever. Indeed, we can turn Nagle and Clancy (2012), who summarising the prevailing positions of many scholars working on Northern Irish issues, show that "social segregation and political polarisation appear to be intensifying” (p. 79).

\section{Titanic Quarter: outlining the project}

TQ stands in a long line of post-industrial waterfront regeneration projects seen around the world, with land being changed from industrial usage to use for housing, leisure and the creative and service industries. Similar sites that helped inform the plans for TQ include Malmo (Sweden), Barcelona (Spain) and the Leith Ocean Terminal (Scotland, where the Royal Yacht Brittannia is kept) (Titanic Quarter, 2005). A number of other studies have focused on waterfront developments in various settings around the world. Desfor and Jørgensen (2004) address flexible governance practices in development in Copenhagen, and Ferreira and Visser (2007) focus on the case of the Victoria and Alfred Waterfront in Cape Town. Jauhiainen (1995) addresses Barcelona, Cardiff and Genoa, while McCarthy (1998) focused on the waterfront at Dundee, Scotland while at the development stage. Jones (1998) reviews a range of UK projects, while Richard Marshall's collection Waterfronts in Post Industrial Cities (2001) surveyed settings as diverse as Bilbao and Shanghai. Specifically in the case of TQ in Belfast, the

establishment of the project was foregrounded by the Laganside Development Corporation, a public body established by set up by the Northern Ireland Office (ministry of the UK government) with the aim of regenerating the area around the Lagan River that 
had largely fallen into disuse. Quoting from architects Shepheard, Epstein and Hunter/BDP, Neill (2006) notes that there was an impetus in Belfast "to transform completely the environmental quality of a vital part of the City, and by this means to help transform perceptions of Belfast at an international level” (p.109). Shirlow and Murtagh (2006), call Laganside "Belfast's most successful attempt to spatially construct the growth economy..." (p.164). In operation from 1989-2007, the primary corporate aim of the Laganside Development Corporation was: "To secure the regeneration of the Laganside designated area to the stage where private sector development and investment will continue without major public intervention" (p.2). However, criticisms of Laganside were heard from different quarters, as Shirlow and Murtagh summarise: Laganside was criticised as "an exclusive Thatcherite property project that failed to connect with the city's disadvantaged and margianalised" (Shirlow and Murtagh, 2006, p.165) (from William Neill), while the OECD argued that it had failed to "impact on the poorest people and areas" (Shirlow and Murtagh, 2006, p.166). Despite this, the valedictory report from Laganside states that the area around the Lagan River had become, following the work of the Laganside Corporation, a "place of opportunity for all" (Laganside Corporation, 2007, p.10) (a theme the report repeats multiple times). In terms of the timing of the setting up of Laganside, triggering the wider development of the area around the River Lagan and the later development of TQ, it should be noted that the impetus for state supported capitalist development of the built-environment preceded the arrival of peace. As Laganside was set up in 1989, this came some five years before the IRA ceasefire of 1994. Before relative peace was secured (many atrocities were still to follow), the regeneration of this area of Belfast was in the planning stage. Across the 
River Lagan from TQ, and about $0.5 \mathrm{~km}$ away, the Belfast Waterfront (originally the Waterfront Hall) was opened in 1997, with the purpose of hosting international concerts and conferences. Built and operated by Belfast City Council, the venue has a place in the history books of the Northern Ireland peace process, as it was the location in May 1998 for John Hume and David Trimble appearing together on stage in an unprecedented show of unity ahead of the referendum on the GFA. One of the first buildings at the site where TQ is located was the Odyssey Arena, an indoor stadium and leisure facility, hosting international concerts and British Ice Hockey team, the Belfast Giants. Opened in 2000, the project was part-funded by the Laganside Development Corporation. Like the Belfast Waterfront, it hosts international concerts, and also conferences, albeit on a much larger scale.

TQ is a site totaling 185 acres, situated at Queen's Island, where the Titanic was built, at the end of Belfast Lough (in east Belfast). The land where TQ is located is "owned by Belfast Harbour Commissioners and leased to Titanic Quarter Limited and Titanic Properties Limited" (Titanic Quarter, 2005, p.2). Despite being termed by one of the involved parties as the "one of the world's largest city centre regeneration projects" (Titanic Quarter, 2005, p.2), the site is not part of the 'city centre' which is approximately $1 \mathrm{~km}$ away (in terms of the CBD), and is rather different in terms of its lack of major shopping outlets compared to the CBD. As noted above, Belfast city centre remains contested, while the area that TQ is located is not contested. The initial Development Framework for TQ planned for "Up to 5000 dwellings including apartments and townhouses; A high quality business quarter. The total business/office/R\&D floor space 
will be $180,000 \mathrm{~m}^{2}$; Commercial development of some $130,000 \mathrm{~m}^{2 "}$ (Titanic Quarter, 2005, p.2). Future plans include the inclusion of "24-acre Science Park; $600,000 \mathrm{sq} \mathrm{ft}$ Financial Services Centre; $1.4 \mathrm{~m} \mathrm{sq} \mathrm{ft}$ commercial space ... 64,000 sq ft movie studio ... up to five hotels; 450,000 sq ft leisure space" (Titanic Belfast, 2011, p.11). As of 2012, there are some eighty companies based there (including Citi Group and Microsoft) and 474 completed apartments, alongside the Public Records Office of NI, and a campus of the city's further education college. Visitors to TQ find a fairly pleasant and interesting space, albeit one which remains quite sparsely filled. It has retained an aura of its maritime past - one can stand on the site where the Titanic was constructed - but gives plenty of clues to its raison d'être as a space for capital accumulation, especially in the apartment blocks that appear garish alongside some buildings at TQ that are over one hundred years old. A relative coup for TQ has been the number of high-profile film and television productions that have been filmed in 'The Paint Hall', currently leased to Northern Ireland Screen. The building that formerly was used for painting Harland and Wolff ships, has been used for the filming of City of Ember (2008), Your Highness (2011) and for the major HBO television series Game of Thrones (2011-) (Titanic Belfast, 2011). The Paint Hall was expanded and renamed Titanic Studios in March 2012. Referring to the production of Game of Thrones, the NI First Minister Peter Robinson stated: "The transformation of the Paint Hall from the last remnant of our once great ship building tradition to the largest stage in Europe is an example of our flexibility and our commitment to innovation" (BBC, 2010). While engaged in the creative industries (as emblematic of the new economy), the developer Harcourt also seeks to tie TQ to history, stating "Once more, the area will be the engine room for the city's growth and economic 
prosperity, while building on and celebrating the maritime history of the area" (Harcourt Developments, 2007, p.15), and that TQ is "firmly rooted in the history and character of Belfast" (Titanic Quarter, 2006). The shift is cast in post-industrial terms by Harcourt Developments, both reflecting and underpinning Belfast's shift from a manufacturing super-power (at its peak it was one of the largest ship builders in the world): "Where once they grew ships, we're now going to grow a community - one of the finest residential, working, educational and office communities." (p.30). But such a claim is rather misleading, suggesting that ship building and post-industrial office spaces in Belfast can be interchangeable, in terms of the employment opportunities they offer. Rather, east Belfast has never had the jobs replaced that were lost with the mass decline of ship building. Here we can evoke Weber (2002), whose critical study of capital accumulation and the built-environment seems very applicable to the case of TQ: "At various points in its circulation, the built environment is junked, abandoned, destroyed, and selectively reconstructed. The physical shells of agin industrial orders may sit dormant for decades before being cleared for a new high-tech "campus"” (p.521).

Understanding the location of $\mathrm{TQ}$ in Belfast from a social and economic perspective is important to setting TQ into the wider context of the political-economic geography of Belfast. Importantly, TQ is located in a traditionally Protestant/Unionist area of Belfast that suffers from deprivation in multiple areas to a relatively large extent, as compared to the rest of Northern Ireland. This is seen in the Northern Ireland Multiple Deprivation Measure (NIMDM), which studies deprivation across seven measurements: "income, employment, health, education, proximity to services, living environment and 
crime" (NISRA, 2010, p.5), across 890 'Super Output Areas', comprised of approximately 2,000 people. A more precise measurement is that of Output Areas (OA), with 5,022 OAs comprised of approximately 350 people. In the 2010 NIMDM findings, if taken as a sub-set of multiple-deprivation, the majority of those areas most deprived in terms of income are located in Belfast and Derry (NISRA, 2010). In terms of multipledeprivation, 24 of the 25 most deprived OAs were in the local government district of Belfast (the one exception being in Derry). The Super Output Area that Titanic Quarter is located in (Island 1) is ranked 90 (out of 890) in terms of Multiple Deprivation. The more precise Output Area (95GG290003) is ranked 1108 (out of 5022) in terms of Multiple Deprivation. If taken across both these measurements, TQ it is located in an area that is the top $10-22 \%$ of the most deprived areas in NI. Showing the great contrasts in Belfast, the least deprived SOA in Northern Ireland - 'Cherryvalley 2' (NISRA, 2010, p.56) - is located only $5 \mathrm{~km}$ away (approximately) from TQ. Surrounded by areas that housed a population employed to a large extent in the shipyards, TQ is located in an area of Belfast that reflects wider social and economic trends in NI that are "a product of the declining structures of traditional industrial capitalism and the new currents of post-industrialism" (Bean, 2007, p.18). In this context, Harvey (2006) mentions Northern Ireland's "longstanding problems ... as a site for capital accumulation" given its history of conflict (p.103). However, Harvey (2010) notes that Northern Ireland is an example of a country where the deprivation and dispossession of people has "little directly to do with capitalist accumulation", and where there is no necessary link to "anti-capitalist politics" (p.247). 


\section{A political-economy of Titanic Quarter}

The corporate structure of the group of companies under Harcourt Developments that have a controlling interest in TQ is complex. Titanic Investments Ltd was incorporated on 11th September 2003, under Jersey law, as a subsidiary of Harcourt Developments. In turn, Titanic Investments Ltd owns Titanic Island Ltd, which itself controls Ivy Wood Properties Ltd. Ivy Wood Properties in turn controls a group of nine subsidiaries that includes Titanic Quarter Ltd, a company registered in NI. Titanic Island Ltd is "the main property development company at the Queen's Island site", and is a financial entity of considerable size in its own right (Simpson, 2011). Simpson (2011) notes that the company’s operating profit in 2010 was $£ 16$ million, while the value of "land and property held for development" in 2011 was £96 million (falling from a 2009 peak of $£ 112$ million). The primary rationale for the development of TQ is economic: to bring economic benefits for the developer, and supposedly to bring economic benefits for the Belfast and wider Northern Irish citizenry. ("The fundamental goal for the development of Titanic Quarter is to achieve high quality investment and development in Belfast") (Titanic Quarter, 2005, p.3). In this respect TQ is no different to wider trends of urban regeneration, the development of the built-environment and the accumulation of capital. For example, Harvey (2008) notes that "since urbanization depends on the mobilization of a surplus product, an intimate connection emerges between the development of capitalism and urbanization" (p.24). Belfast, as is discussed elsewhere in this article, is particularly susceptible to this kind of development, given its history of violence and the destruction of vast swathes of its built environment. Indeed for Harvey, 
urbanization takes its place alongside military expenditure as one of the key sites in the economy for "absorbing the surplus product that capitalists perpetually produce in their search for profits" (Harvey, 2008, p.25). However, Harcourt Developments chose to focus in their promotional literature not on the economic benefits it was due to reap, but rather on the wider benefits to the area and the city. Thus Harcourt Developments (2007) suggested the "development is expected to create at least 20,000 new jobs over the next 15 years, and bring in $£ 1.5$ billion of investment" (p.15), (or 30,000 jobs and $£ 2$ billion of investment over a 20 year period) (p.17), claims made before the global financial crises that may be significantly limited in their realisation.

Another main reason for the development of $\mathrm{TQ}$ is to bring benefit to the construction industry. NI has relied on this in part for the underpinning of its economy, especially in the replacement of other parts of its economy which have been in decline (especially in manufacturing output, in line with the rest of the UK). Within five years since the TQ Master Plan being published (2006-2011), construction contracts at TQ were valued at $£ 175 \mathrm{~m}$, which it was claimed had gone on the whole to NI companies (Titanic Quarter, 2011). In 2011, 500 construction workers were working at TQ, which according to the developer Harcourt Developments (through the subsidiary Titanic Quarter Ltd.) made it "the largest building site on the island of Ireland" (Titanic Quarter, 2011). This $£ 175$ m was called by Mike Smith, then TQ Ltd’s CEO “a 'down payment' for the local economy" (Titanic Quarter, 2011). Smith's proposition is debatable from an economic point of view and one that needs tested, given the limited effect overall that TQ might have throughout NI, and rather as a project that primarily benefits the developer. 
His statement is also ideological to the extent that it suggests that construction firms might play a more fundamental role in the political culture in NI. In this sense, companies like Harcourt Developments have come to see themselves as being indispensable political-economic actors, benignly benefiting the people of NI with their construction projects. Corroboration to this claim is given in a 2005 statement by Harcourt, who claimed that in relation to Belfast, TQ is "essential to the future prosperity of the city as a whole" (Titanic Quarter, 2005, p.1), a claim that is not quantifiable, at least in the short to medium term. Despite this - as is shown below in a section on TQ and local and regional government - developers like Harcourt enjoy almost unequivocal support for their activities from various bodies of the state and of government, and from individual politicians, in a way that is not proportionate with the benefits they have brought to the economy and to Northern Ireland society. The extent which this is the case was encapsulated in a statement by Peter Robinson, when he argued that Titanic Belfast was "one of the key projects we are looking for, for our tourist industry... with massive potential for the construction industry ... This is the very kind of project we need to assist in these difficult financial times" (BBC, 2008).

\section{The Titanic visitor centre}

At the centre of TQ lies the $£ 77$ million Titanic 'Signature Building', Titanic Belfast, which opened in 2012. It was conceptualised by CivicArts, and designed by Todd Architects (BBC, 2012d). The majority of the funding for the building came from 
the public sector (Department of Enterprise (DETI) - NI Tourist Board £36.95m; Belfast Harbour Commissioners £13.6m; Belfast City Council £10m) (Magee, 2012). Harcourt Developments paid $£ 16.35 \mathrm{~m}$ towards its cost through Titanic Quarter Ltd (representative of 21.2 per cent of the total cost). While the building is owned by a charitable trust Titanic Foundation Ltd — "All proceeds from the building belong to the centre operator Titanic Belfast Ltd" (owned by Harcourt Developments) (“A charitable trust, Titanic Foundation Ltd will own the building. The operator has to pay Titanic Foundation Ltd $£ 200 \mathrm{k}$ and put $£ 600 \mathrm{~K}$ into a trust each year to refresh the attraction”) (Magee, 2012). Here is it is worthy of note that while DETI applied for part of the public funding for the project to be supplied by the EU, the EU "has questioned the application on the basis there was a lack of competition in Titanic Quarter Ltd (TQL) selecting an associated company, Harcourt Construction (NI) Ltd to undertake the building work" (Magee, 2012). As things stand the EU have noted the strong connections between public and private sectors, and have problematised the extent to which Harcourt Developments may be set to benefit considerably from extensive public funding, with considerable amounts of public finance becoming subsumed by private capital. Perhaps one of the most noteworthy features of Titanic Belfast is that "Based on projected visitor numbers, it is one of the most expensive buildings of its kind in Europe ... Per visitor, it cost more than Disneyland in Paris, is almost three times more expensive than the Guggenheim in Bilbao, and cost about seven times more than the Tate Modern" (Magee, 2012). Despite this concern therefore over the wider viability of the project, Arlene Foster - the Democratic Unionist Party minister responsible for tourism in NI — blamed the media for "fuelling and giving voice to negativity about the scheme", and noted that she was 
“'frustrated to the ends of the earth' by people talking down the Titanic Signature project" (as cited in Shapiro, 2012). This is seen in the light of the wider context of the DUP blaming the local press and media for its perceived negative coverage of its legislative agenda; for the DUP, the press should also be a cheer leader for economic development (see the March 2009 letter from Peter Robinson, jointly with Deputy First Minister Martin McGuinness criticising the Belfast Telegraph's journalism on the NI Executive Programme For Government) (OFMDFM, 2009).

\section{Titanic Quarter and the relationship with local and regional government}

The supporting role of local government in the development of TQ was rather fundamental to its progression, and the project received widespread political and financial support from local and regional government in NI. At Belfast City Council, Gerry Copeland evoked the concept of a 'blank canvas' (which will be explored in more detail later), underlining the role in the economic development of local government as a 'cheerleader' for development: "That area of the city has obviously declined since its industrial use. But now we have almost a blank canvas and an opportunity to create a new future and to shift the whole city, east of the river" (in reference to the River Lagan which bisects Belfast) (as cited in Harcourt Developments, 2007, p.37). Moreover, Peter McNaney, Chief Executive of Belfast City Council stated: "It ticks all the right boxes: introducing new industries and increasing the skills base to help diversify the city's employment base into the knowledge economy..." (Harcourt Developments, 2007, p.17). 
In this respect, McNaney's vision is realised in the Citi Group complex at TQ, which placed a 'Centre of Excellence' in Belfast, serving its European operations. The then Lord Mayor of Belfast, Cllr. Pat Convery argued TQ "will generate not just significant economic benefits, but a wide range of social benefits which have the potential to improve the quality of life for everyone in the City" (Titanic Quarter, 2010). Quite what these social benefits are, or how they could be realised in an area of significant multiple depravation, such as the one in which TQ is located, is something that remains to be seen. Viewing TQ as something for all the people of Belfast (or NI is a problematic notion), which is something that the rhetoric from elected local politicians or local government officials rarely fully addresses. Rather, such language goes to offer further support for capital accumulation, despite mentioning the obligatory benefits for the wider population of Belfast. One level up from local government in NI is the Northern Ireland Assembly, within which the Executive holds devolved powers on a range of legislation from Westminster, and works in tandem with the ROI government through the North-South ministerial council. Here, the majority view was that the establishment of TQ was positive. One dissenting view came from Dawn Purvis, then a member of the Northern Ireland Assembly for the minor unionist party, the Progressive Unionist Party (representing the East Belfast constituency which contains TQ). While Purvis called TQ "fantastic news", she noted that the project might have limited benefit for working class people in East Belfast: "It's not just about offering jobs - it's about building the capacity and skills of the people in order to take up those opportunities" (BBC, 2008). Some similar criticism was seen in the words of Robin Newton, a DUP MLA. Newton argued, critically, that the project needed to bring social as well as economic benefits to the 
people of the area:

All too often we have seen as part of the so-called gentrification process, shiny new apartment blocks going up, built by companies and workmen with no connections to the local community, which are effectively segregated from the neighbourhoods in which they appear and occupied by people with no stake in the local community - this cannot be the case in East Belfast. (Newton, 2007)

\section{Wider political discourse and Titanic Quarter}

As Secretary of State for NI, the New Labour Minister Peter Hain stated: "Our shared vision is that the whole TQ development will make a unique contribution to regenerate and revitalise this site and contribute to a more prosperous future for Northern Ireland" (Harcourt Developments, 2007, p.43). As a statement from a New Labour minister, there is nothing particularly surprising in Hain's point. What it does show is that at the UK national level NI's progress is to be viewed through a lens of economic development realised in capital accumulation in the built-environment. More significant was the interpretation of his statement by Harcourt Developments, that argued: "This is probably one of the only times that a British government minister has said something that all the people of Belfast can agree with" (Harcourt Developments, 2007, p.43). Here Harcourt Developments seems to be suggesting that economic development trumps politics, and that the reduction of violent political conflict can lead two historically opposed communities to share in the interests of capitalist development. But more than this, the view of Harcourt is that it must develop in this way. Any ambiguity on this point was dispelled by Conal Harvey, director of operations at Harcourt Developments. He 
argued "Northern Ireland's future must be driven economically. Everything hangs on people having the lifestyle opportunities, and reasons to put their history of conflict behind them. TQ is symbolic of the new Northern Ireland" (Harcourt Developments, 2007, p.17). Perhaps the statement is particularly pointed for the Nationalist population (who favour the joining of NI with ROI). The notion is clear: post-GFA, nationalists need no longer to be concerned with political struggle, but instead simply need to focus on the transition to being a consumer-driven 'normal society'. Indeed, Martin McGuinness (as NI's Deputy First Minister, 2007—present) has stuck very close to the pro-business line of the Democratic Unionist Party. McLaughlin and Baker (2010) in The Propaganda of Peace highlight one of the watershed moments in this transition, when at the opening of the IKEA store in Belfast (December 2007) Ian Paisley of the DUP and Martin McGuinness sat on an IKEA sofa beneath the slogan 'Home is the Most Important Place in the World' (cf. Jewesbury and Porter, 2010). Following the GFA and the St. Andrews agreement, the setting up of the power sharing institutions and relative peace, there is an agreed interpretation: peace has come; it is time to have a normal society; today, normal societies spend money. The best way to reach conflict resolution is to turn the antagonists into consumers. Rather than fighting on the streets, Northern Ireland's people ought to be fighting for the best bargains in the aisles.

\section{A 'pleasingly blank' canvas: viewing Belfast's 'post-conflict' spaces}

In its promotional literature for TQ, Harcourt Developments is especially frank about how it views urban development in Belfast in light of the Troubles: 
Belfast is unique among Western European cities in that more than half of its city centre has yet to be redeveloped, creating a pleasingly blank canvas for regeneration. True, the circumstances that led to this are unfortunate. The violence that plagued the province for 32 years, until peace was declared by the IRA, meant that Belfast was completely underdeveloped and under- regenerated compared to English cities of the same size. (Harcourt Developments, 2007, p.44)

To link NI's recent past of violence so explicitly to development potential in a public document is quite revealing, and shows the extent to which the city of Belfast is seen by developers as a space for development and capital accumulation, despite its history. To say the circumstances are 'unfortunate' is grossly inadequate. It is correct that due to the violent past of NI, the built-environment was blighted in such a way that it left many prime development sites free for development. While the immediate area that TQ is located in was spared the levels of violence seen elsewhere, Harcourt Developments appear to take a wider view of Belfast and the potential it offers. Following the cessation of the worst levels of the Troubles, the development of the built-environment in Belfast offers developers the opportunity to accumulate large amount of capital. To do so, Belfast has become seen and indeed constructed in discourse as a post-conflict city (MacKenzie and Porter, 2011). Jewesbury and Porter (2010) note that economic and political forces have coalesced to shape "the image of contemporary Belfast" in such a way (p.35). The development of a post-conflict city involves for Jewesbury and Porter (2010) the development of a "moralising politics of social and economic development" (p.36):

By this we mean that there is a strong connection between the twin narratives of political progress and social-economic development in contemporary Belfast; that post-Agreement Belfast has, to a significant degree, become a story in which the twin moral goods of political progress and privatised, neo-liberal economic development are folded into one another. (Jewesbury and Porter, 2010, p.36) 
To apply this argument directly to TQ, we can say that the development has wrapped up with it 'twin moral goods' they refer to. TQ is cast as being emblematic of the 'New Northern Ireland', where political progress enables a leisure culture based around consumption. TQ is cast as a prime example of how private economic development, with the support of public finance, can supposedly benefit the whole of the economy and by extension the people of NI. Political process and economic development, when realised through construction, can thus realise the "normative promise of the depoliticisation or neutralisation of public space" central to establishing "Belfast as a post-conflict city" (Jewesbury and Porter, 2010, p.35).

\section{Conclusion}

The claim that TQ will benefit all of the people of NI is problematic. While there has been modest stimulation of the wider construction sector as a result of the project, and a largely disused industrial site has been made more aesthetically pleasing, the primary benefactors from TQ are Harcourt Developments. The discourse that surrounds TQ that is almost entirely supportive — from local politicians and from the media (this article has not had the space to deal with this latter group) - needs to become much

more critical, shifting to a place that is more reflective of wider political-economic conditions in NI, and the lack of impact that a project like TQ has on the average citizen. NI has struggled with the move to 'conventional economics', especially with regards to 
the property market. While many enjoyed high rewards from rising property values for a period, the market has now all but collapsed and may take many years to recover. Large property developers continue to speculate in NI, despite the collapse. While greatly reduced property prices might be expected to lead to a more equitable market, early suggestions are that those with the resources will simply purchase more property than ever, thus entrenching inequality. Rather than moving to further marketisation, politicians with responsibility for NI need to realise that this is not necessarily the best economic path. Here it could be suggested that UK government needs to consider NI a special economic case for decades to come, with the subvention continuing for a long time yet. Moreover, TQ provides a concrete case study of how the so-called 'New Northern Ireland' was established through the coalescing of political and economic forces, and how historical conditions can be neatly negated for the opportunity of development. The violent history of Northern Ireland suggests that it should never be considered a "pleasingly blank canvas", but rather as a space blighted by violence with great human cost attached. Future research on Titanic Quarter may be strengthened by conducting interviews with representatives from Harcourt Developments and relevant government agencies, and also with local and regional politicians. What is clear is that research needs to continue to focus on the development of the built-environment in Belfast and Northern Ireland, and to continue to question the assumption capital accumulation benefits the wider population. 


\section{Acknowledgements}

I would like to thank Robert Porter, Steve Baker and Daniel Jewesbury who commented on earlier drafts of this article. I would also like to thank the participants of Dramatizing the Political - A One Day Symposium at the University of Ulster, 17 September 2010, who offered some insightful feedback on a presentation of a previous version of this article. Finally, I would like to acknowledge the important comments provided and criticisms offered by the anonymous reviewers. 


\section{References}

BAIRNER, A. (2006) The flâneur and the city: Reading the 'new' Belfast's leisure spaces, Space and Polity, 10(2), pp. 121-134.

BBC (2008) Titanic project 'to benefit all', BBC, 28 November 2008

(http://news.bbc.co.uk/2/hi/uk_news/northern_ireland/7754078.stm; accessed 29 May 2012).

BBC (2010) Game of Thrones fantasy epic to be filmed in Belfast, BBC, 03 March 2010 (http://news.bbc.co.uk/2/hi/uk_news/northern_ireland/8547516.stm; accessed 09 June 2012).

BBC (2011) Value of Victoria Square drops by $£ 29 m, B B C, 08$ November 2011 (http://www.bbc.co.uk/news/uk-northern-ireland-15640723; accessed 21 July 2012).

BBC (2012a) RBS chairman concerned by performance of Ulster Bank, BBC, 9 June 2012 (http://www.bbc.co.uk/news/uk-northern-ireland-18378580; accessed 17 July 2012).

BBC (2012b) RBS doubles annual loss in 2011, fourth since bailout, BBC, 23 February 2012 (http://www.bbc.co.uk/news/business-17128477; accessed 14 July 2012).

BBC (2012c) CastleCourt shopping centre in Belfast sold, BBC, 14 February 2012 (http://www.bbc.co.uk/news/uk-northern-ireland-17036214; accessed 06 August 2012).

BBC (2012d) Titanic plans to transform Belfast's cityscape, BBC, 06 April 2012 (http://www.bbc.co.uk/news/uk-northern-ireland-17625133; accessed 09 August 2012).

BEAN, K. (2007) The New Politics of Sinn Féin. Liverpool: Liverpool University Press.

BELFAST INTERFACE PROJECT (2012) Belfast Interfaces Security Barriers and Defensive Use of Space. Belfast: Belfast Interface Project.

BYRNE, J., HANSSON, U. and BELL, J. (2006) Shared Living Mixed residential communities in Northern Ireland. Belfast: Institute for Conflict Research.

CANNING, M. (2012) Northern Ireland property prices drop by $48 \%$ in five years, Belfast Telegraph, 10 July 2012 (http://www.belfasttelegraph.co.uk/news/localnational/northern-ireland/northern-ireland-property-prices-drop-by-48-in-five-years16183054.html; accessed 25 July 2012).

DARBY, J. (2003) Northern Ireland: The background to the Peace Process, University of 
Ulster: CAIN (http://cain.ulst.ac.uk/events/peace/darby03.htm; accessed 12 September 2012).

DESFOR, G. and JØRGENSEN, J. (2004) Flexible urban governance. The case of Copenhagen's recent waterfront development, European Planning Studies, 12(4), pp.479496.

FERREIRA, S. and VISSER, G. (2007) Creating an African Riviera: Revisiting the Impact of the Victoria and Alfred Waterfront Development in Cape Town, Urban Forum, 18(3), pp. 227-246.

FITZPATRICK, J. (2012) Report says Nama is selling NI property 'slowly', BBC 1 June 2012 (http://www.bbc.co.uk/news/uk-northern-ireland-18283209; accessed 13 July 2012).

HAMILTON, J., HANSSON, U., BELL, J. and TOUCAS, S. (2008) Segregated Lives: Social Division, Sectarianism and Everyday Life in Northern Ireland. Belfast: Institute for Conflict Research.

HARCOURT DEVELOPMENTS (2007) TQ: Titanic Quarter - Regenerating Belfast, 2007, No. 1. London: 3 Fox International.

HARVEY, D. (2006) Spaces of Global Capitalism: Towards a Theory of Uneven Geography. London: Verso.

HARVEY, D. (2008) The Right to the City, New Left Review, 53, pp. 23-40.

HARVEY, D. (2010) The Enigma of Capital and the Crises of Capitalism. London: Profile Books.

INVEST NORTHERN IRELAND (2012) Annual Report and Accounts. Belfast: Invest Northern Ireland.

JAUHIAINEN, J. (1995) Waterfront redevelopment and urban policy: The case of Barcelona, Cardiff and Genoa, European Planning Studies, 3(1), pp.3-23.

JEWESBURY, D. and PORTER, R. (2010) On Broadway, in: The Centrifugal Book of Europe, pp. 34-53. Belfast: Centrifugal.

JONES, A. (1998) Issues in Waterfront Regeneration: More Sobering Thoughts-A UK Perspective, Planning Practice \& Research, 13(4), pp. 433-442.

KAUFMANN, E. (2012) Northern Ireland Symposium: The Northern Ireland Peace Process in an Age of Austerity, The Political Quarterly, 83(2), pp.203-209.

LAGANSIDE CORPORATION (2007) Laganside Corporation 1989-2007: Regeneration Statement. Belfast: Laganside Corporation 
MACKENZIE, I. and PORTER, R. (2011) Dramatizing the Political: Deleuze and Guattari. Basingstoke: Palgrave MacMillan.

MAGEE, K. (2010) NI unemployment figures back to 1998 levels, BBC, 15 September 2010 (http://www.bbc.co.uk/news/uk-northern-ireland-11315299; accessed 16 September 2010).

MAGEE, K. (2012) Titanic Belfast: Will it rival Disneyland, Tate Modern and the Guggenheim?, BBC, 29 March 2012 (http://www.bbc.co.uk/news/uk-northern-ireland17552802; accessed 10 June 2012).

MARSHALL, R. (ed.) (2001) Waterfronts in Post Industrial Cities. London: Spon Press.

MCALISTER, R. (2009) Improved Ways of Living or Continued Exclusion? Experiences of Participation in Belfast's Urban Transformation, ENQUIRE, 2, pp.1-30.

MCCARTHY, J. (1998) Waterfront regeneration: Recent practice in Dundee, European Planning Studies, 6(6), pp. 731-736.

MCLAUGHLIN, G. and BAKER, S. (2010) The Propaganda of Peace: The Role of Media and Culture in the Northern Ireland Peace Process. Bristol: Intellect.

NAGLE, J. (2009a) Sites of Social Centrality and Segregation: Lefebvre in Belfast, a "Divided City", Antipode, Vol. 41(2), pp. 326-347.

NAGLE, J. (2009b) The right to Belfast City Centre: From ethnocracy to liberal multiculturalism?, Political Geography, 28( 2), pp. 132-141.

NAGLE, J. and CLANCY, M.A. (2012) Constructing a shared public identity in ethno nationally divided societies: comparing consociational and transformationist perspectives, Nations and Nationalism, 18(1), pp. 78-97.

NEILL, W. (2006) Return to Titanic and Lost in the Maze: The Search for Representation of 'Post-conflict' Belfast, Space and Polity, 10(2), pp. 109-120.

NEWTON, R. (2007) Titanic Quarter Must Deliver Benefits to All, Says Newton (http://www.robinnewton.co.uk/articles-and-speeches/39-newsflash/268-where-did-theinstaller-go.html; accessed 04 January 2013).

NIO (1998) The Agreement: Agreement reached in the multi-party negotiations (http://www.nio.gov.uk/agreement.pdf; accessed 14 September 2010).

NIO (2007) Agreement at St. Andrews (http://www.nio.gov.uk/st_andrews_agreement.pdf; accessed 10 June 2012).

NISRA (2010) Northern Ireland Multiple Deprivation Measure 2010: May 2010. Belfast: NISRA. 
NISRA (2012) Census 2011: Population and Household Results for Northern Ireland, 16 July 2012 (http://www.nisra.gov.uk/Census/pop_press_release_2011.pdf; accessed 10 August 2012).

NOLAN, P. (2012) Northern Ireland Peace Monitoring Report: Number One. Belfast: Community Relations Council.

OFMDFM (2009) Letter to Sir Anthony O’Reilly, COR/129/2009. Belfast: OFMDFM.

PORTLAND TRUST (2007) Economics in Peacemaking: Lessons from Northern Ireland. London: Portland Trust.

SHAPIRO, Y. (2012) Can Titanic's hopes stay afloat?, BBC, 22 January 2012

(http://www.bbc.co.uk/news/uk-northern-ireland-16666231; accessed 10 June 2012).

SHIRLOW, P. (2006) Belfast: The 'post-conflict' city, Space and Polity, 10(2), pp. 99107.

SHIRLOW, P. and MURTAGH, B. (2006) Belfast: Segregation, Violence and the City. London: Pluto Press.

SIMPSON, J. (2011) Company Snapshot: Titanic Island Ltd, Belfast Telegraph, 20 December 2011 (http://www.belfasttelegraph.co.uk/business/company-profiles/companysnapshot-titanic-island-ltd-16093300.html; accessed 06 August 2012).

TITANIC BELFAST (2011) A New Icon for the New Belfast. Belfast: Titanic Belfast.

TITANIC QUARTER (2005) Titanic Quarter: Development Framework. Belfast: Titanic Quarter.

TITANIC QUARTER (2006) Corporate Message (http://www.titanicquarter.com/about.php?ID=3; accessed 10 June 2012).

TITANIC QUARTER (2010) Titanic Opportunities For All (http://www.titanicquarter.com/readpress.php?CID=1\&ID=73; accessed 11 June 2012).

TITANIC QUARTER (2011) Titanic Quarter Construction Generate $£ 175 \mathrm{~m}$ in Contracts, 10 January 2011 (http://www.titanic-quarter.com/readpress.php?CID=1\&ID=74; accessed 10 June 2012).

WEBER, R. (2002) Extracting Value from the City: Neoliberalism and Urban Redevelopment, Antipode, 34(3), pp. 519-540. 